\title{
IMPLEMENTASI KEBIJAKAN DALAM MITIGASI BENCANA BANJIR DI DESA DAYEUHKOLOT
}

\author{
Feny Irfany Muhammad ${ }^{1) *}$, Yaya M Abdul Aziz ${ }^{2)}$ \\ ${ }^{1)}$ Program Studi Magister Administrasi dan Kebijakan Publik, Universitas Pasundan \\ Bandung, Jawa Barat, Indonesia \\ feny.muhammad@mail.unpas.ac.id \\ ${ }^{2)}$ Program Studi Magister Administrasi dan Kebijakan Publik, Universitas Pasundan \\ Bandung, Jawa Barat, Indonesia \\ mulyana_yaya@unpas.ac.id
}

\begin{abstract}
ABSTRAK
Banjir merupakan bencana yang dianggap lumrah terjadi di Dayeuhkolot karena seringnya terjadi banjir pada daerah tersebut. Banjir disebabkan perkembangan metropolitan cekungan Bandung sangat pesat. Perkembangan tersebut terlihat dari semakin memadatnya bangunan dan meningkatkan area kedap air, pembuangan berbagai jenis limbah ke sungai yang mengakibatkan sedimentasi yang besar di sungai Citarum dan eksploitasi air tanah sehingga terjadi penurunan muka tanah dari tahun ke tahun. Hadirnya Perda Kabupaten Bandung Nomor 02 Tahun 2013 sebagai upaya dalam penanggulangan bencana diharapkan mampu menjadi solusi dalam pemecahan masalah banjir di kabupaten Bandung. Namun demikian sejak Perda tersebut dilahirkan 6 Tahun lalu, bencana banjir masih kerap terjadi hingga kini. Hal tersebut terjadi karena komunikasi yang belum berjalan baik antara masyarakat dengan pemangku kebijakan serta sumberdaya yang ada belum memadai untuk meimplementasikan Perda tersebut. Metode penelitian yang peneliti gunakan adalah penelitian survey dengan pendekatan kualitatif. Kerlinger (1973) mengemukakan bahwa, penelitian survey adalah penelitian yang dilakukan pada populasi besar maupun kecil, tetapi data yang dipelajari adalah data dari sampel yang diambil dari populasi tersebut, sehingga ditemukan kejadian-kejadian relative, distribusi, dan hubunganhubungan antar variable sosiologis maupun psikologis. Berdasarkan hasil pembahasn, Implementasi Kebijakan Mitigasi Bencana Banjir oleh BPBD Desa Dayeuhkolot Kabupaten Bandung belum berjalan dengan maksimal, masih terdapat permasalahan dan kendala yang dihadapi dalam pelaksanaan tersebut. Hal ini ditandai dengan Pencegahan Bencana Banjir, Penanganan Darurat Bencana Banjir, Rehabilitasi dan Rekontruksi bencana banjir masih banyak ditemukan permasalahan.
\end{abstract}

Kata Kunci: Implementasi Kebijakan, Mitigasi Bencana.

\begin{abstract}
Floods are disasters that are considered commonplace in Dayeuhkolot due to frequent flooding in the area. The flood was caused by the rapid development of the metropolitan basin of the Bandung basin. This development can be seen from the increasingly compacting of buildings and increasing watertight areas, disposal of various types of waste into the river which has resulted in large sedimentation in the Citarum river and exploitation of groundwater resulting in a decrease in land surface from year to year. The presence of Bandung Regency Regional Regulation Number 02 of 2013 as an effort in disaster management is expected to be a solution in solving the problem of flooding in Bandung district. However, since the Perda was enacted 6 years ago, flood disasters still occur frequently until now. This occurs because communication is not yet going well between the community and policy makers and the available resources are not sufficient to implement the Perda. The research method that researchers use is survey research with a qualitative approach. Kerlinger (1973) argues that survey research is research carried out in large and small populations, but the data studied is data from samples taken from that population, so that relative incidents, distribution, and relationships between sociological and social variables are found. psychological. Based on the results of the discussion, the
\end{abstract}




\section{Kebijakan: Jurnal Ilmu Administrasi \\ Volume 11, Nomor 1, Januari 2020 \\ E-ISSN: 2656-2820 \\ P-ISSN 1829-5762}

implementation of the Flood Disaster Mitigation Policy by the BPBD of Dayeuhkolot Village, Bandung Regency has not run optimally, there are still problems and obstacles faced in this implementation. This is indicated by the Flood Disaster Prevention, Flood Disaster Emergency Management, Rehabilitation and Reconstruction of flood disasters. There are still many problems found.

Keywords: Policy Implementation, Disaster Mitigation.

\section{PENDAHULUAN}

Banjir merupakan bencana alam yang terjadi di kawasan yang banyak dialiri oleh aliran sungai. Sedangkan secara sederhana, banjir diartikan sebagai hadirnya air ke suatu kawasan luas sehingga menutupi permukaan bumi kawasan tersebut, contohnya Desa Dayeuhkolot kecamatan Dayeuhkolot kabupaten Bandung merupakan salah satu wilayah di Cekungan Bandung, Jawa Barat, yang rentan terhadap bahaya banjir. Kondisi ini dipengaruhi oleh keberadaan Sungai Citarum sebagai sumber banjir dan pengaruh pengelolaan pembangunan di sekitar Daerah Aliran Sungai (DAS). Dampak bertambah besarnya pengaruh faktor-faktor tersebut dari tahun ke tahun, bencana banjir tidak dapat dihindari oleh masyarakat yang bermukim di sekitar daerah aliran sungai Citarum. Hingga saat ini, bencana banjir setiap tahun selalu terjadi di wilayah daerah aliran sungai Citarum, terutama di kecamatan Dayeuhkolot. Pemerintah membentuk badan penyelenggaraan penanggulangan bencana merupakan serangkaian upaya yang meliputi penetapan kebijakan pembangunan yang berisiko timbulnya bencana, kegiatan pencegahan bencana, tanggap darurat, dan rehabilitasi. Penanggulangan bencana merupakan tugas dan tanggung jawab pemerintah yang harus dilakukan secara menyeluruh dan terpadu pada setiap tahapan melalui Badan Penanggulangan Bencana baik yang berada di Pusat yaitu Badan Nasional Penanggulangan Bencana (BNPB) maupun yang berada di daerah yang disebut BPBD.

BPBD kabupaten Bandung dibentuk atas dasar bahwa letak dan kondisi geografis, geologis dan demografis wilayah kabupaten Bandung rawan terhadap terjadinya bencana dengan frekuensi yang cukup tinggi. Bencana tersebut disebabkan baik oleh faktor alam, non alam maupun manusia yang menyebabkan timbulnya korban jiwa manusia, kerusakan lingkungan, kerugian harta benda dan dampak psikologis yang dalam keadaan tertentu dapat menghambat proses pemerintahan, pembangunan dan kemasyarakatan. Rangkaian bencana yang dialami kabupaten Bandung, telah mengembangkan kesadaran mengenai kerawanan dan kerentanan masyarakat. Sikap reaktif dan pola penanggulangan bencana yang dilakukan dirasakan tidak lagi memadai. Dibutuhkan pengembangan sikap baru yang lebih proaktif, menyeluruh, dan mendasar dalam menyikapi bencana. Pola penanggulangan bencana mendapatkan dimensi baru dengan dikeluarkannya Undang-Undang No. 24 tahun 2007 Tentang Penanggulangan Bencana yang diikuti beberapa aturan pelaksana terkait, yaitu Peraturan Presiden Nomor 08 tahun 2008 Tentang Badan Nasional Penanggulangan Bencana, Peraturan Pemerintah (PP) Nomor 21 Tahun 2008 Tentang Penyelenggaraan Penanggulangan Bencana, PP Nomor 22 Tahun 2008 Tentang Pendanaan dan Pengelolaan Bantuan Bencana, PP Nomor 23 Tahun 2008 Tentang Peran Serta Lembaga Internasional dan Lembaga Asing non Pemerintah Dalam Penanggulangan Bencana, Peraturan Menteri Dalam Negeri Nomor 46 Tahun 2008 dan Peraturan Kepala Badan Nasional Penanggulangan Bencana. Nomor 3 Tahun 2008 Tentang Pedoman Pembentukan Badan Penanggulangan Bencana Daerah. Dimensi baru dari rangkaian peraturan terkait dengan bencana tersebut adalah:

1. Penanggulangan bencana sebagai sebuah upaya menyeluruh dan proaktif dimulai dari Pra bencana seperti mitigasi, kesiapsiagaan, sedangkan tanggap darurat dengan melaksanakan evakuasi penduduk, pemenuhan kebutuhan pangan, layanan kesehatan dan penampungan, dan kegiatan pasca 


\section{Kebijakan: Jurnal Ilmu Administrasi \\ Volume 11, Nomor 1, Januari 2020 \\ E-ISSN: 2656-2820 \\ P-ISSN 1829-5762}

bencana dengan melaksanakan rehabilitasi dan rekonstruksi.

2. Penanggulangan bencana sebagai upaya yang dilakukan bersama oleh para pemangku kepentingan dengan peran dan fungsi yang saling melengkapi.

3. Penanggulangan bencana sebagai bagian dari proses pembangunan sehingga mewujudkan ketahanan (resilience) terhadap bencana.

Berbagai kebijakan tersebut telah ditindaklanjuti oleh pemerintah kabupaten Bandung dengan adanya Perda Kabupaten Bandung No 2 Tahun 2013 Tentang Penyelenggaraan Penanggulangan Bencana di Kabupaten Bandung. Perda ini sebagai langkah konkrit pemerintah daerah dalam regulasi kebijakan penanggulangan bencana. Perda ini diharapkan menjadi solusi dalam penanggulangan bencana yang mungkin terjadi. Salah satu bencana yang menjadi perhatian peneliti dalam penanggulangannya adalah mengenai implementasi kebijakan mitigasi bencana banjir yang tiap tahun pasti terjadi. Bencana banjir di daerah kabupaten Bandung yang diakibatkan oleh meluapnya Sungai Citarum, terjadi di daerah Pameungpeuk, Baleendah, Dayeuhkolot, Bojongsoang, Majalaya, Cicalengka dan Rancaekek, banjir terjadi akibat meluapnya air di beberapa sungai yang melintasi daerah tersebut, yaitu Sungai Cibodas, Cisangkuy, yang terjadi berulangkali, yaitu tahun 1931, 1964, 1992, hingga sekarang. Wilayah bencana banjir yang dipilih oleh peneliti adalah di wilayah Desa Dayeuhkolot kecamatan Dayeuhkolot. Dipilihnya wilayah tersebut dikarenakan merupakan salah satu wilayah yang paling sering terkena banjir di wilayah kabupaten Bandung. Desa Dayeuhkolot merupakan kawasan di kabupaten Bandung yang berada di sisi sungai Citarum. Berdasarkan sejarah, Dayeuhkolot yang dalam bahasa sunda berarti kota tua, merupakan ibu kota sekaligus pusat pemerintahan kabupaten Bandung. Lokasinya sangat strategis yang terletak di pertemuan sungai Cikapundung dengan sungai Citarum sebagai muaranya karena pada saat itu sungai menjadi jalur transportasi utama. Pada zaman kolonial Belanda, ibu kota harus dipindahkan 10 kilometer ke arah utara atau ke lokasi kota Bandung sekarang karena pada saat itu sedang dibangun jalan raya Post atau jalan raya Anyer-Panarukan yang membentang dari ujung barat hingga ujung timur pulau Jawa untuk mempermudah keterhubungan kota-kota di pulau/Jawa. Selain itu, banjir yang sering melanda Dayeuhkolot menjadi alasan utama ibu kota kabupaten harus dipindahkan. Kota madya diubah statusnya menjadi kota Bandung dan memiliki sistem pemerintahan baru. Oleh karena itu, kabupaten Bandung harus mencari ibu kota baru sebagai pusat pemerintahannya. Dayeuhkolot tidak dipilih kembali menjadi ibukota kabupaten dengan alasan sering mengalami banjir. Maka, ibu kota kabupaten Bandung dipindahkan ke kecamatan Soreang. Walaupun demikian, Dayeuhkolot mengalami pembangunan yang pesat. Hal tersebut dikarenakan Dayeuhkolot merupakan sasaran ekspansi metropolitan Bandung sekaligus pintu gerbang ke wilayah Bandung Selatan. Dayeuhkolot memiliki dominasi fungsi permukiman dan perdagangan. Tidak hanya itu, Dayeuhkolot juga menjadi sasaran beberapa industri besar dan menarik masyarakat untuk bekerja dan menetap disana.

Dayeuhkolot merupakan salah satu pusat kegiatan dan memiliki peranan penting bagi kabupaten Bandung. Banjir merupakan bencana yang dianggap lumrah terjadi di Dayeuhkolot karena seringnya terjadi banjir pada daerah tersebut. Hal tersebut tentu saja menyebabkan kerugian yang besar, diantaranya membuat aktivitas masyarakat terganggu, kerusakan bangunan, munculnya wabah penyakit, terhambatnya kegiatan ekonomi, dan terganggunya konektivitas antara kota Bandung dengan wilayah Bandung Selatan. Banjir disebabkan perkembangan metropolitan cekungan Bandung sangat pesat. Perkembangan tersebut terlihat dari semakin memadatnya bangunan dan meningkatkan area kedap air, pembuangan berbagai jenis limbah ke sungai yang mengakibatkan sedimentasi yang besar di sungai Citarum dan eksploitasi air tanah sehingga terjadi penurunan muka tanah dari tahun 


\section{Kebijakan: Jurnal Ilmu Administrasi Volume 11, Nomor 1, Januari 2020 E-ISSN: 2656-2820 P-ISSN 1829-5762}

ke tahun. Hadirnya Peraturan Daerah Kabupaten Bandung Nomor 02 Tahun 2013 sebagai upaya dalam penanggulangan bencana diharapkan mampu menjadi solusi dalam pemecahan masalah banjir di kabupaten Bandung. Namun demikian sejak Perda tersebut dilahirkan 6 Tahun lalu, bencana banjir masih kerap terjadi hingga kini. Hal mendasar dalam menyoroti permasalahan dalam Mitigasi bencana banjir desa dayeuhkolot membutuhkan perhatian banyak pihak sebab permasalahan banjir Desa Dayeuhkolot merupakan Pertanggung jawaban publik, oleh sebab itu komunikasi merupakan bagian penghubung antara masyarakat dengan pemangku kebijakan. Sehingga permasalahan yang ada akan dapat menghasilkan suatu implementasi yang baik. Birokrasi dapat memberikan jaminan lebih besar untuk tercapainya kebijakan dalam penyelesaian masalah mitigasi bencana banjir di desa Dayeuhkolot. Pemberian izin bagi pembangunan yang akan memberikan dampak pada masyarakat luas seharusnya melalui proses dengar pendapat publik. Tak hanya dari pemerintah dan pihak terkait, dibutuhkan sumber daya yang berkopenten agar kesadaran masyarakat untuk memelihara lingkungan dapat terminimalisir, dampak dari bencana banjir di desa Dayeuhkol. Pada akhirnya dengan keasadaran dari semua pihak, upaya Mitigasi bencana banjir di desa Dayeuhkolot diharapkan dapat teratasi. Dari permasalahan di atas, peneliti tertarik mengambil judul penelitian mengenai Implementasi Kebijakan dalam Mitigasi Bencana Banjir di desa Dayeuhkolot Kabupaten Bandung. Adapun fokus pada penelitian ini ialah di desa Dayeuhkolot kecamatan Dayeuhkolot kabupaten Bandung Jawa Barat. Penelitian yang peneliti lakukan pasti memiliki tujuan tertentu. Berdasarkan latar belakang dan rumusan masalah yang telah penulis uraikan diatas, maka tujuan diadakannya penelitian ini adalah untuk mengetahui sejauh mana implementasi kebijakan Mitigasi Bencana Banjir di desa Dayeuhkolot kecamatan Dayeuhkolot kabupaten Bandung diterapkan.

\section{METODE}

Metode penelitian yang peneliti gunakan adalah penelitian survey dengan pendekatan kualitatif. Kerlinger (1973) mengemukakan bahwa, penelitian survey adalah penelitian yang dilakukan pada populasi besar maupun kecil, tetapi data yang dipelajari adalah data dari sampel yang diambil dari populasi tersebut, sehingga ditemukan kejadian-kejadian relatif, distribusi, dan hubungan-hubungan antar variabel sosiologis maupun psikologis. Metode penelitian merupakan cara yang dilakukan peneliti dalam menganalisis data untuk memberikan solusi terhadap suatu kondisi yang bermasalah. Metode penelitian juga pada dasarnya merupakan cara ilmiah untuk mendapatkan data dengan tujuan dan kegunaan tertentu. Peneliti akan menguji dari teori yang dikemukan oleh Edward III mengenai implementasi kebijakan publik, selanjutnya peneliti membuat dan menguji rumusan masalah dari teori tersebut, terakhir peneliti mengoperasionalisasikan variabel-variabel yang ada dari teori tersebut. Sumber data merupakan subjek dari mana data dapat diperoleh. Penelitian ini merupakan penelitian deskriptif maka pada penelitian ini hanya menggunakan informan sebagai sumber data penelitian, sehingga untuk memperoleh data yang dibutuhkan secara jelas, mendetail, akurat dan terpercaya hanya bisa diperoleh melalui informan. Peneliti menyebutkan akan melakukan wawancara mendalam untuk mengumpulkan data-data yang akan memperkuat hasil analisis peneliti. Narasumber atau informan yang akan diwawancarai oleh peneliti adalah : Kepala Desa Dayeuhkolot, Camat Dayeuhkolot, BPBD Kabupaten Bandung, Masyarakat yang mengetahui penerapan kebijakan Mitigasi Bencana Banjir dan LSM yang berperan sebagai salah satu lembaga bukan pemerintah yang peduli terhadap lingkungan dan membantu pemerintah dalam menangani masalah banjir. 


\section{Kebijakan: Jurnal Ilmu Administrasi \\ Volume 11, Nomor 1, Januari 2020 \\ E-ISSN: 2656-2820 \\ P-ISSN 1829-5762}

\section{PEMBAHASAN}

Pada bagian ini akan dibahas mengenai bagaimana implementasi kebijakan Mitigasi Bencana Banjir di desa Dayeuhkolot yang dilakukan Pemerintah Desa Dayeuhkolot Kabupaten Bandung, evaluasi dari implementasi kebijakan tersebut, dan faktor-faktor apa saja yang dihadapi Pemerintah Desa Dayeuhkolot Kabupaten Bandung dalam menanggulangi kejadian bencana yang terjadi. Untuk membahas mengenai implementasi kebijakan, peneliti menggunakan indikator dari Edward III dan evaluasi menggunakan kriteria menurut William Dunn. Menurut Edward III dalam Agustino (2006:157-158) transmisi komunikasi merupakan penyaluran komunikasi. Sehingga penyaluran komunikasi yang baik akan dapat menghasilkan suatu implementasi yang baik pula. Namun, seringkali terjadi masalah dalam penyaluran komunikasi yaitu adanya salah pengertian (miskomunikasi) yang disebabkan banyaknya tingkatan birokrasi yang harus dilalui dalam proses komunikasi, sehingga apa yang diharapkan terdirtorsi di tengah jalan. Berdasarkan hasil penelitian Edward III yang dirangkum dalam Winarno (2005:127) Terdapat beberapa hambatan umum yang biasa terjadi dalam transmisi komunikasi yaitu : "Pertama, terdapat pertentangan antara pelaksana kebijakan dengan pemerintah yang dikeluarkan oleh pembuat kebijakan. Pertentangan seperti ini akan mengakibatkan distorsi dan hambatan yang langsung dalam komunikasi kebijakan. Kedua, informasi yang disampaikan melalui berlapis-lapis hierarki birokrasi. Distorsi komunikasi dapat terjadi karena panjangnya rantai informasi yang dapat mengakibatkan bias informasi. Ketiga, masalah penangkapan informasi juga diakibatkan oleh persepsi dan ketidakmampuan para pelaksana dalam memahami persyaratan-persyaratan suatu kebijakan". Dalam hal ini, Peneliti melakukan wawancara bersama Kepala Desa Dayeuhkolot kecamatan Dayeuhkolot kabupaten Bandung yang menyatakan bahwa: "Komunikasi penanganan masalah banjir sudah berjalan, meskipun måsih ada yang harus ditingkatkan dalam komunikasi ini untuk dapat berjalan konsisten agar dapat menangani masalah banjir secara menyeluruh".

Dari penuturan diatas mengindikasikan bahwa kurang sinkronisasi komunikasi antara masyarakat dan pihak pemangku kebijakan himbauan/yang disosialisasikan oleh pemerintah terhadap masyarakat untuk mengantisipasi segala kemungkinan yang bisa terjadi. Ini mengindikasikan bahwa peran pemerintah sangat penting dalam melaksanakan konsep manajemen penanggulangan bencana yang bertujuan untuk memberdayakan masyarakat. Informan menyatakan bahwa untuk dekat dengan masyarakat dibentuk posko darurat penanggulangan bencana ketika terjadinya bencana banjir di Desa Dayeuhkolot. Posko ini dibentuk agar masyarakat yang terkena bencana dapat segera tertolong. Posko tersebut dilengkapi dengan beberapa peralatan dan logistik. Berdasarkan penuturan diatas bahwa pembentukan posko darurat penanggulangan bencana diperlukan, hal ini dilakukan untuk mempermudah akses komunikasi Kebijakan Mitigasi Bencana Banjir yang mengalami hambatan untuk memperoleh informasi, selain itu juga diharapkan sistem ini dapat diterapkan untuk seluruh masyarakat di lingkungan Desa Dayeuhkolot kecamatan Dayeuhkolot kabupaten Bandung.

Dalam menanggulangi bencana banjir, pemerintah daerah terkait untuk meminimalisir terjadinya banjir. Efektivitas suatu kebijakan pemerintah tidak akan berarti apabila mengenai bencana banjir dan masyarakat yang menjalankan kebijakan tersebut dari pemerintah. Pemerintah sebagai pelayan yang dibutuhkan oleh masyarakat dalam mengatasi banjir. Pemerintah harus melakukan hal-hal yang mengurangi banjir seperti membuat waduk yang dapat menampung air hujan dan menyediakan tempat sampah agar masyarakat tidak membuang sampah sembarangan serta masyarakat juga harus mempunyai kesadaran untuk menjaga lingkungan. Pemerintah dan masyarakat dapat bekerjasama untuk menanggulangi banjir dan melakukan penghijauan atau 


\section{Kebijakan: Jurnal Ilmu Administrasi \\ Volume 11, Nomor 1, Januari 2020 \\ E-ISSN: 2656-2820 \\ P-ISSN 1829-5762}

penanaman pohon di sekitar lahan kosong. Menurut Undang-Undang Nomor 24 Tahun 2007, bencana adalah peristiwa atau rangkaian peristiwa yang mengancam dan mengganggu kehidupan dan penghidupan masyarakat yang disebabkan, baik oleh faktor alam atau faktor non alam maupun faktor manusia sehingga mengakibatkan timbulnya korban jiwa manusia, kerusakan lingkungan, kerugian harta benda dan dampak psikologi. Menurut Edward III dalam Agustino (2006:157-158) konsistensi perintah merupakan perintah yang diberikan dalam pelaksanaan suatu komunikasi harus konsisten dan jelas untuk ditetapkan atau dijalankan. Jika perintah yang diberikan sering berubah-ubah, maka dapat menimbulkan kebingungan bagi pelaksana di lapangan.

Dapat diambil kesimpulan bahwa dalam transmisi informasi mengenai sistem penangulangan masyarakat Kebijakan Mitigasi Bencana Banjir tersalurkan dengan baik. Sehingga sebagian masyarakat Kebijakan Mitigasi Bencana Banjir di BPBD Desa Dayeuhkolot Kecamatan Dayeuhkolot Kabupaten Bandung. Dari beberapa pernyataan informan di atas dapat diketahui bahwa para informan melaksanakan anjuran mengenai sistem penangulangan yang diberlakukan oleh BPBD Desa Dayeuhkolot Kecamatan Dayeuhkolot Kabupaten Bandung. Maka dapat diketahui bahwa konsistensi pemerintah mengenai anjuran untuk melaksanakan mitigasi bencana banjir sudah dilakukan langsung oleh BPBD dan masyarakat Kebijakan Mitigasi Bencana Banjir, walaupun dalam pelaksanaannya masih ada beberapa warga yang tidak mengetahui mengenai kegiatan tersebut. Menurut Edward III dalam Agustino (2006:158-159), sumberdaya merupakan hal penting dalam implementasi kebijakan yang baik. Sumber daya utama dalam implementasi kebijakan adalah staf atau pegawai (street-level bureaucrats). Kegagalan yang sering terjadi dalam implementasi kebijakan, salah satunya disebabkan oleh staf/pegawai yang tidak cukup memadai, mencukupi, ataupun tidak kompeten dalam bidangnya. Penambahan jumlah staf dan implementor saja tidak cukup menyelesaikan persoalan implementasi kebijakan, tetapi diperlukan sebuah kecukupan staf dengan keahlian dan kemampuan yang diperlukan (kompeten dan kapabel) dalam mengimplementasikan kebijakan.

Dalam hal ini, Peneliti melakukan wawancara bersama Kepala Desa Dayeuhkolot Kecamatan Dayeuhkolot Kabupaten Bandung yang menyatakan bahwa: "Secara umum Sumber Daya Manusia desa Dayeuhkolot memang kurang memahami cara kesiapsiagaan menanggani bencana banjir yang pernah terjadi di desa Dayeuhkolot ini". Informan mengatakan bahwa ada beberapa persoalan yang menyebabkan pelaksanaan Mitigasi bencana di BPBD Desa Dayeuhkolot Kecamatan Dayeuhkolot Kabupaten Bandung terkendala, yaitu salah satunya disebabkan oleh kurangnya fasilitas kebencanaan dari pihak pemerintah seperti kebutuhan rescue dan para relawan tanggap bencana. Oleh Karena itu informan berharap Pemerintah Daerah, bisa terus membenahi dan memperbaiki kebijakan yang diberlakukannya. Dari beberapa informasi diatas, maka dapat diketahui bahwa BPBD Desa Dayeuhkolot Kecamatan Dayeuhkolot Kabupaten Bandung sudah memiliki tim rescue tanggap bencana yang kompeten dan mau untuk melaksanakan tugasnya dengan baik, hanya saja ada beberapa kendala terkait dengan kebijakan maupun hal-hal lainnya yang membuat ada beberapa pegawai yang terlihat kurang respon dalam pelayanan tanggap bencana kepada para masyarakat. Menurut Edward III dalam Agustino (2006:158-159) wewenang pada umumnya merupakan kewenangan harus bersifat formal agar perintah dapat dilaksanakan secara efektif. Kewenangan merupakan otoritas atau legitimasi bagi para pelaksana dalam melaksanakan kebijakan yang ditetapkan secara politik. Ketika wewenang tidak ada, maka kekuatan para implementor di mata publik tidak dilegitimasi, sehingga dapat menggagalkan implementasi kebijakan publik. Tetapi dalam konteks yang lain, ketika wewenang formal tersedia, maka sering terjadi kesalahan dalam melihat efektivitas kewenangan. di satu pihak, efektivitas kewenangan diperlukan dalam 


\section{Kebijakan: Jurnal Ilmu Administrasi \\ Volume 11, Nomor 1, Januari 2020 \\ E-ISSN: 2656-2820 \\ P-ISSN 1829-5762}

implementasi kebijakan; tetapi di sisi lain, efektivitas akan menyurut manakala wewenang diselewengkan oleh para pelaksana demi kepentingannya sendiri atau kelompoknya.

Untuk memperkuat pernyataan tersebut maka peneliti melakukan wawancara kepada Bapak H. Gun Gun Gunawan sebagai wakil Bupati Kabupaten Bandung, menyatakan bahwa : "persoalan banjir dayeuhkolot tentu menjadi tanggung jawab bersama termasuk masyarakat. Pemerintah Kabupaten Bandung akan menerima saran secara terbuka dari berbagai kalangan, untuk bersamasama mengatasi persoalan banjir itu, keterlibatan masyarakat dapat berupa saran masukan yang nantinya akan kita akomodir dalam kebijakan Pemerintah Kabupaten Bandung, bahkan permasalahan ini sudah menjadi masalah nasional". Berdasarkan pernyataan informan maka dapat diketahui bahwa peran serta pemerintah merupakan salah satu kunci dalam penanganan bencana banjir yang menyeluruh. Bukan hanya itu dengan keterlibatan langsung pemerintah dan masyarakat dalam menanggulangi bencana merupakan salah satu langkah yang pasti dalam menemukan solusi dari permasalahan yang terjadi.

Dari seluruh informasi di atas, maka dapat diketahui bahwa wewenang formal baik dalam pengelolaan maupun dalam pelaksanaan mitigasi bencana banjir masi perlu adanya pembenahaan baik dari sisi sumberdaya bahkan sampai dengan anggaran, sebab BPBD Desa Dayeuhkolot kecamatan Dayeuhkolot kabupaten Bandung ini perlu untuk menjaga kualitas pelayanannya terhadap seluruh masyarakat. Menurut Edward III dalam Agustino (2006:158-159) fasilitas yang mendukung antara lain merupakan fasilitas fisik merupakan faktor penting dalam implementasi kebijakan. Implementor mungkin mempunyai staf yang mencukupi, kapabel dan kompeten, tetapi tanpa adanya fasilitas pendukung (sarana dan prasarana) maka implementasi kebijakan tersebut tidak akan berhasil. Dalam hal ini, Peneliti melakukan wawancara bersama Kepala Desa Dayeuhkolot Kecamatan Dayeuhkolot Kabupaten Bandung yang menyatakan bahwa: "Salah satu faktor penghambat dalam Implementasi Kebijakan Mitigasi Bencana Banjir yang terjadi di desa Dayeuhkolot ini yaitu kurangnya dana dari pemerintah, sehingga dalam Implementasi Kebijakan Mitigasi Bencana Banjir itu biasanya kurang memadai”. Informan menyatakan bahwa fasilitas untuk mendukung Kebijakan Mitigasi Bencana Banjir yang tersedia terlihat tidak mencukupi untuk dilihat dari Alat yang ada di BPBD (Badan Penanggulangan Bencana Daerah) ini tidak lengkap atau tidak memadai untuk digunakan dalam penanggulangan bencana banjir, karena apabila ada terjadi bencana biasanya alat yang digunakan itu biasanya tidak kembali lagi di instansi tersebut. Menurut Edward III dalam Wianarno (2005:142-143) mengemukakan kecenderungan-kecenderungan atau disposisi merupakan salah-satu faktor yang mempunyai konsekuensi penting bagi implementasi kebijakan yang efektif. Jika para pelaksana mempunyai kecenderungan atau sikap positif atau adanya dukungan terhadap implementasi kebijakan maka terdapat kemungkinan yang besar implementasi kebijakan akan terlaksana sesuai dengan keputusan awal. Demikian sebaliknya, jika para pelaksana bersikap negatif atau menolak terhadap implementasi kebijakan karena konflik kepentingan maka implementasi kebijakan akan menghadapi kendala yang serius.

Berdasarkan pernyataan informan diatas maka dapat diketahui bahwa memandang penting para staf / pegawai di lingkungan BPBD Kabupaten Bandung dan Desa Dayeuhkolot Kecamatan Dayeuhkolot Kabupaten Bandung sebagai sumber daya utama dalam melaksanakan pelayanan terhadap warga yang terkena dampak bencana Banjir Dayeuhkolot. Oleh Karena itu seluruh warga masyarakat, relawan dan pegawai yang dimiliki perlu mengikuti program pelatihan Mitigasi bencana alam yang diberikan untuk dapat meningkatkan kemampuan dan keahlian yang dimiliki. Dari seluruh pernyataan yang dikemukakan oleh informan di atas, maka dapat diketahui bahwa telah ada pengangkatan pegawai (birokrat) yang sesuai dengan prosedur dengan didasari oleh landasan hukum 


\section{Kebijakan: Jurnal Ilmu Administrasi Volume 11, Nomor 1, Januari 2020 E-ISSN: 2656-2820 P-ISSN 1829-5762}

yang jelas. Selain itu juga akan dilakukan pendataan oleh Badan Kepegawaian Daerah, khususnya untuk para pegawai kontrak yang akan diangkat menjadi pegawai tetap. Menurut Edward III dalam Agustinus (2006:159-160) pengelolaan insentif merupakan salah-satu teknik yang disarankan untuk mengatasi masalah sikap para pelaksana kebijakan dengan memanipulasi insentif. Pada dasarnya orang bergerak berdasarkan kepentingan dirinya sendiri, maka memanipulasi insentif oleh para pembuat kebijakan mempengaruhi tindakan para pelaksana kebijakan. Dengan cara menambah keuntungan atau biaya tertentu mungkin akan menjadi faktor pendorong yang membuat para pelaksana menjalankan perintah dengan baik. Hal ini dilakukan sebagai upaya memenuhi kepentingan pribadi atau organisasi. Sehingga, dapat didikatakan bahwa indikator pengelolaan sudah dijalankan dengan sebaik-baiknya oleh BPBD Desa Dayeuhkolot Kecamatan Dayeuhkolot Kabupaten Bandung dengan didasarkan pada dasar hukum yang kuat. Menurut Edwards III dalam Winarno (2005:150) standard operational procedure (SOP) merupakan perkembangan dari tuntutan internal akan kepastian waktu, sumber daya serta kebutuhan penyeragaman dalam organisasi kerja yang kompleks dan luas. Ukuran dasar SOP atau prosedur kerja ini biasa digunakan untuk menanggulangi keadaan-keadaan umum diberbagai sektor publik dan swasta. Dengan menggunakan SOP, para pelaksana dapat mengoptimalkan waktu yang tersedia dan dapat berfungsi untuk menyeragamkan tindakan-tindakan pejabat dalam organisasi yang kompleks dan tersebar luas, sehingga dapat menimbulkan fleksibilitas yang besar dan kesamaan yang besar dalam penerapan peraturan.

Untuk mengukur dimensi struktur Birokrasi di BPBD Kabupaten Bandung sebagai Badan Penangulangan Bencana sekaligus mitra dari Kebijakan Mitigasi Bencana Banjir, maka dapat diukur melalui indikator Standar Operasional Procedure. Untuk itu peneliti melakukan wawancara dengan salah satu Kebijakan Mitigasi Bencana Banjir, Kepala Desa Dayeuhkolot Kecamatan Dayeuhkolot Kabupaten Bandung yang menyatakan bahwa: "Para relawan bencana yang bertugas menangani masyarakat yang terkena dampak Bencana Banjir dengan cukup teliti selama melayani dan sabar dalam menangani keluhan masyarakat". Oleh karena itu, dapat diketahui bahwa dalam memberikan pelayanan di BPBD Kabupaten Bandung telah melakukan sesuai dengan standar operasional prosedur yang berlaku. Selain itu juga tidak ada perbedaan pelayanan kepada seluruh masyarakat Desa Dayeuhkolot Kecamatan Dayeuhkolot Kabupaten Bandung khususnya masyarakat yang terkena dampak Bencana Banjir. Menurut Edward III dalam Winarno (2005:155) menjelaskan bahwa fragmentasi merupakan penyebaran tanggung jawab suatu kebijakan kepada beberapa badan yang berbeda sehingga memerlukan koordinasi. Pada umumnya, semakin besar koordinasi yang diperlukan untuk melaksanakan kebijakan, semakin berkurang kemungkinan keberhasilan program atau kebijakan. Dari seluruh pernyataan di atas maka dapat diketahui bahwa BPBD Desa Dayeuhkolot Kecamatan Dayeuhkolot Kabupaten Bandung sudah menerapkan atau melaksanakan kebijakan Sehingga ketika Kebijakan Mitigasi Bencana Banjir mulai diberlakukan pada tanggal 1 April 2014. Leo Agustino (2014: 45-46) mengatakan bahwa kebijakan publik pasti akan dibentuk dan membentuk lingkungan sekitarnya. Artinya, interaksi antara lingkungan kebijakan dan kegiatan kebijakan publik memiliki hubungan yang saling berpengaruh. Terdapat beberapa bentuk lingkungan yang dapat mempengaruhi kegiatan kebijakan publik, diantaranya variabel politik dan sosial ekonomi yang disebut-sebut sebagai dua variabel penting pertama untuk dibahas dalam memahami pengaruhnya terhadap kebijakan yang tercipta.

Berikut merupakan hasil temuan di lapangan terkait hubungan antara lingkungan kebijakan (politik dan sosial ekonomi) dengan kegiatan kebijakan yang menjadi faktor pendorong maupun 


\section{Kebijakan: Jurnal Ilmu Administrasi Volume 11, Nomor 1, Januari 2020 E-ISSN: 2656-2820 P-ISSN 1829-5762}

penghambat Pemerintah Kabupaten Bandung dalam menanggulangi bencana banjir di kawasan Desa Dayeuhkolot pada awal tahun 2013-2014.

1. Pelaksanaan pembuatan tanggul yang telah dilakukan pemerintah belum maksimal sehingga upaya perbaikan tanggul terkesan masih tambal sulam, seperti tanggul yang kembali rusak, ataupun limpasan ketika air datang. Begitu pun dengan upaya peninggian tanggul yang dimaksudkan agar tidak terjadi lagi limpasan malah menyebabkan kedalaman air yang masuk ke kawasan desa Dayeuhkolot dirasakan masyarakat semakin tinggi karena peninggian tanggul tersebut tidak diiringi oleh pengerukan sungai yang sudah lama tidak dilakukan.

2. Kurangnya personil BPBD di wilayah desa dayeuhkolot, SOP (Standar Operating Procedures), dan peraturan daerah yang secara khusus mengatur tentang penanggulangan bencana di kabupaten Bandung menyebabkan penyebaran tanggung jawab yang diberikan pemerintah kepada SKPD dan stakeholder dalam Satuan Pelaksana Penanggulangan Bencana (Satlak PB) menimbulkan ketidakjelasan dan kesalahpahaman karena disamping tidak memiliki lembaga yang dapat dijadikan panutan atau power, para personil pun mengalami kesulitan karena tidak memiliki pedoman yang dapat dijadikan acuan dalam melakukan upaya penanggulangan bencana. Ketiadaan BPBD, SOP, dan peraturan daerah yang secara khusus mengatur tentang penanggulangan bencana juga menyulitkan dalam melakukan koordinasi karena penanganan bencana yang dilakukan kurang terfokus.

3. Kurang personil BPBD juga menyebabkan sulitnya pemerintah di dalam menetapkan status tanggap darurat. Begitu pun dengan pengangkatan personil yang dilakukan dibentuk hanya pada saat mendekati waktu bencana datang. Selain itu, pengangkatan personil yang didapatkan dari Badan Kepegawaian Daerah (BKD) pun kurang memiliki kompetensi dalam bidang kebencanaan sehingga masih perlu dilakukan pelatihan secara berkesinambungan untuk dapat terjun di lapangan.

4. Terdapat peran dari masyarakat sekitar dalam upaya penanggulangan bencana melalui kesadaran terhadap bahaya bencana banjir dengan membuat organisasi masyarakat yang dinamakan Masarakat Relawan Indonesia. Organisasi masyarakat ini mendapat bantuan berupa sarana dan prasarana yang berasal swasta berupa pendirian posko dan peralatan evakuasi. MRI memberikan masyarakat informasi mengenai status ketinggian sehingga masyarakat dapat segera melakukan persiapan dalam menghadapi bencana banjir. Selain itu, pernah dilakukannya swadaya oleh masyarakat untuk menambal bagian tanggul yang retak dan bocor.

5. Masih sulitnya menggerakan masyarakat untuk dapat bergabung menjadi bagian dari relawan kebencanan yang dapat bergabung dengan BPBD ataupun Masyarakat Relawan Indonesia (MRI) di kawasan Desa Dayeuhkolot.

6. Masih minimnya anggaran yang dialokasikan dalam APBD untuk mengatasi seluruh kejadian bencana di Kabupaten Bandung menyebabkan upaya untuk menanggulangi kejadian bencana menjadi terbatas, seperti masih terbatasnya pengadaan fasilitas (sarana dan prasarana) penanggulangan bencana di Kabupaten Bandung.

\section{KESIMPULAN}

Berdasarkan hasil pembahasan di atas maka dapat disimpulkan bahwa Implementasi Kebijakan Dalam Mitigasi Bencana Banjir oleh BPBD Desa Dayeuhkolot Kabupaten Bandung belum berjalan dengan maksimal, masih terdapat permasalahan dan kendala yang dihadapi dalam pelaksanaan tersebut. Hal ini ditandai dengan Pencegahan Bencana Banjir, Penanganan Darurat Bencana Banjir, Rehabilitasi dan Rekontruksi bencana banjir masih banyak ditemukan permasalahan. Pada aspek pencegahan bencana banjir tersebut masih ditemui permasalahan- 


\section{Kebijakan: Jurnal Ilmu Administrasi \\ Volume 11, Nomor 1, Januari 2020 \\ E-ISSN: 2656-2820 \\ P-ISSN 1829-5762}

permasalahan seperti pelaksanaan pembuatan peta rawan bencana khususnya bencana banjir, pelaksanaan pemantauan rutin yang belum tampak oleh masyarakat serta pelatihan kesigapan belum dirasakan masyarakat sehingga pencegahan dan penanganan bencana belum dirasakan seutuhnya oleh masyarakat. Perlunya penerapan metode sosialisasi yang lebih praktis sehingga masyarakat lebih mudah memahami. Pada aspek penanganan darurat bencana banjir terlihat belum berjalan maksimal di sebabkan karna kurangnya personil / anggota BPBD yang ada yang belum terlalu turun membantu masyarakat saat terjadi bencana banjir, peralatan yang belum memadai seperti tenda yang masih kurang perahu karet banyak yang rusak, sarana dan prasarana sewaktu terjadinya banjir belum sepenuhnya ada. Pada aspek rehabilitasi dan rekontruksi bencana banjir terlihat belum berjalan maksimal buktinya seperti koordinasi yang dijalankan antara pemerintah dan masyarakat belum berjalan dengan baik dan optimal guna menentukan titik rawan bencana, masih banyak bangunanbangunan yang lama belum dilakukan perehapan seperti tanggul dan gorong-gorong, pelaksanaan rekostruksi dan rehabilitasi belum merata. Jadi, Implementasi Kebijakan Mitigasi Bencana Banjir oleh BPBD Desa Dayeuhkolot Kabupaten Bandung masih belum optimal bahkan hampir sama sekali tidak dirasakan oleh masyarakat.

\section{DAFTAR PUSTAKA}

Abidin, Said Zainal. 2004. Cetakan Kedua. Kebijakan Publik Edisi Revisi. Jakarta: Yayasan Pancur Siwah.

Herdianyah, Haris. 2010. Metodologi Penelitian Kualitatif Untuk Ilmu-Ilmu Sosial. Jakarta: Salemba Humanika.

Hosio, Jusach Edi. 2007. Cetakan Kedua. Kebijakan Publik Dan Desentralisasi: Esai-Esai Dari Sorong.Yogyakarta: Laksbang Yogyakarta.

Hutomo. (1999). Cetakan Keempat. Prinsip-Prinsip Kebijaksanaan Negara. Malang: Bumi Aksara.

Islamy, M. Irfan. 2002. Prinsip-prinsip Perumusan Kebijakan Negara. Jakarta: Cetakan Kesebelas Bumi Aksara.

Indiahono, Dwiyanto. 2009. Kebijakan Publik Berbasis Dynamic Public Analisys. Yogyakarta: Gava Media.

Keban, Yeremias. T, 2004. Enam Dimensi Strategis Administrasi Publik, Konsep Teori dan Isu. Yogyakarta: Gaya Media.

Lubis, Solly. 2007. Kebijakan Publik. Bandung: Mandar Maju.

Nawawi, Ismail. 2009. Public Policy: Analisis, Strategi Advokasi Teori, dan Praktek. Surabaya: CV. Putra Media Nusantara.

Nugroho, Riant. 2008. Public Policy. Jakarta: Alex Media Komputindo.

Pasolong, Harbani. 2010. Teori Administrasi Publik. Bandung: Alfabeta.

Putra, Fadillah. 2001. Paradigma Kritis Dalam Studi Kebijakan Publik. Surabaya: Pustaka

Pelajar Offset.

Sjahrir. 1987. Kebijaksanaan Negara: Konsistensi dan Implementasi. Jakarta: LP3ES.

Subarsono, AG. 2009. Analisis Kebijakan Publik Konsep, Teori, dan Aplikasi. Yogyakarta: Pustaka Pelajar. 2005. Analisis Kebijakan Publik. Yogyakarta: Pustaka Pelajar.

Suharto, Edi. 2008. Cetakan Keempat. Analisis Kebijakan Publik.Bandung: CV. Alfabeta. 


\section{Kebijakan: Jurnal Ilmu Administrasi \\ Volume 11, Nomor 1, Januari 2020}

E-ISSN: 2656-2820

P-ISSN 1829-5762

Kebijakan Publik Yang Membumi. Jakarta: Lukman Offset.

T. Keban, Yeremias. 2008. Enam Dimensi Strategis Administrasi Publik.Yogyakarta: Gava Media.

Tangkilisan, Hessel Nogi. S. 2003. Implementasi Kebijakan Publik. Jakarta: Lukman Offset..

Wahab, Solichin Abdul. 2005. Analisis Kebijakan dari Formulasi ke Implementasi Kebijakan Negara. Jakarta: Bumi Aksara.

Wahyudi, Isa. et al. 2008. Memahami Kebijakan Publik dan Strategi Advokasi: Sebuah Panduan Praktis. Malang: In-Trans Publishing.

Warpani, S. 1990. Merencanakan Sistem Perangkutan. Bandung: Penerbit ITB.

Wibawa, Samodra. 1994. Kebijakan Publik Proses dan Analisis. Jakarta: Intermedia.

Wibowo, S.S. 2016 Slide Presentasi: Expert Forum Intelektual: Catatan Kritis Transportasi Bandung. HTI Bandung Raya.

Widodo, Joko. 2007. Analisis Kebijakan Publik: Konsep dan Aplikasi Analisis Proses Kebijakan Publik. Malang: Bayu Media

Winarno, Budi. 2002. Teori dan Proses Kebijakan Publik. Yogyakarta: Media Pressindo. 